\title{
Relating the Learning Styles, Dependency, and Working Memory Capacity to Performance Effectiveness in Collaborative Problem Solving
}

\author{
Kaveh Sheikhrezaei ${ }^{1}$, Craig Harvey ${ }^{1(\varpi)}$ \\ ${ }^{1}$ Louisiana State University, Baton Rouge, LA \\ harvey@1su.edu
}

\begin{abstract}
Although much research has concentrated on the forecast of efficient team performance and the variables that might detract or promote team efficiency, little research reviewed has assessed the multitude of individual characteristics their impact on collaborative problem solving (CPS). Much of the research investigates only a single individual characteristic and its effect on group performance. This research proposes to explore three individual attributes (interpersonal dependency, individual working memory capacity, and preferred learning style) on performance effectiveness in CPS. A wide range of fields including healthcare and the military has explored CPS; however, the bulk of teamwork research to date has dealt with behavioral coordination on a single feature. This study will explore the association between team-member attributes and CPS skills. Noteworthy interactions might be observed to demonstrate that there are mixtures of traits more (or less) productive than anticipated, indicating further evidence of how group composition influences group performance.
\end{abstract}

Keywords: Human Factors · Collaborative Problem solving · Individual differences Factors · Performance Effectiveness

\section{Introduction and Literature Review}

As the use of groups has increased, research studies concentrating on the forecast of efficient team performance and the variables that might detract or promote team efficiency has actually increased [1], [2], and [3]. Collaborative problem solving (CPS) is being used in a variety of group task environments (e.g. face-to-face) specifically for novel or non-routine tasks. Several research studies and reports indicate the importance of CPS [4], [5], [6], and [7].

Most complex problems require that teams work together to find solutions. The very principle of collaborative problem solving (CPS) is merging the individuals' knowledge to accomplish common goals. Lack of education and training in CPS provides an opportunity to recognize strategies to improve CPS. Researchers that have studied CPS have identified opportunities and challenges for the development of research on CPS [5]. The latest improvements in digital technologies can be employed to automate the CPS processes along with the detection and evaluation of different CPS competencies. If this is successful, digital 
technologies will allow investigators to gather and evaluate very large sets of data in a varied range of tasks, settings, and populations. This would make significant progress in discriminating theories, testing hypotheses and developing an educational curriculum for CPS training and education. In the past, understanding of team members' communication was a challenge in evaluating collaboration [5].

In general, collaborative problem solving has two primary parts: the collaborative (e.g., social aspects or communication) and the cognitive aspects or knowledge (e.g., domain-specific problem-solving techniques) [8]. These two parts are frequently described as "task work " and "teamwork". The individual problem solving and collaborative problem solving are different from the social part in the context of a group task. Problem-solving requires team's exchange ideas, communicate, and problem solve with their team mates.

There are numerous and varied instances of collaborative problem-solving activities from casual class activities to large-scale official assessments of cooperation by online training systems [9]. There is likewise substantial research on the elements that impact the achievement of collaborative performance and collaborative learning [10].

Even with a growing quantity of organizations performing tasks using groups, little is understood how people included in a team impact intragroup procedures and results. The predominant theory of considering groups is the input-- process - output design [11], [12], [13], and [14]. According this model, intragroup procedures and outputs are affected by the inputs integrate. According to Hackman [1], inputs are classified into the three groups: group level factors (e.g., team composition), individual-level factors (e.g., team-member qualities), and environmental-level elements (e.g., task attributes).

Early researchers (e.g., [15]; [16]) assumed that team composition affected both team processes and outputs. Further, Senior \& Swailes [17] have recognized team composition as a crucial aspect that affects team performance. The composition considers the personal characteristics of participants (e.g., ability, experience, and skill) as well as how they can possibly integrate to determine total efficiency results for the group. Regardless of the understanding of team composition elements value [18], few researchers have studied the result of nondemographic attributes on team processes and outcomes. For instance, self-report procedures of skill, knowledge, collectivism, experience, group size, and flexibility as composition variables have been used in two different research [19] and [20]. The considerable relations among these composition elements and team process and efficiency measures have been shown by the researchers. Additionally, Yazici [21] found evidence that shows the value of learning style preferences to involve learners in different collaborative tasks and to design effective varied teams. Future research is needed to understand critical individual characteristics (e.g., learning style, dependency, and working memory capacity) of team members and their interactive effect upon team member performance.

\subsection{Team Composition (Group Level Factors)}

Team composition describes the general mix of attributes amongst individuals in a group, which is a component of at least two people who 
connect interdependently to attain a common goal [22]. As a result, team composition has actually been a popular subject. In theory, team composition research study goes to the heart of comprehending how individual characteristics integrate to form effective interdependent groups.

\subsection{Team-Member Attributes (Individual-level factors)}

Human performance can be influenced for many reasons (e.g. age, mental state, physical health, personal attitude, emotions, and cognitive biases). In this research, characteristics such as interpersonal dependency, individual working memory capacity, or preferred learning style are hypothesized to contribute considerably to the variation in group performance efficiency.

\subsubsection{Learning Styles}

Learning styles point to a number of competitive and controversial theories whose purpose is to recognize differences in the individuals' learning processes [23]. These theories suggest that all individuals can be categorized based on the style of "learning" though different theories offer different perspectives on how to define and classify them [23]. A common opinion is a difference in ways that people learn something [24]. Individualized learning styles have been considered since the 1970s [23] and has significantly impacted education in spite of the received criticism from some researchers [25].

Individuals have various learning styles characteristic preferences and strengths in their way of capturing and processing information. While some tend to the emphasize facts, algorithms, and data; others are more interested in mathematical models and theories. Some people respond more to graphical information forms, like diagrams, schematics, and pictures; some individuals are more comfortable with spoken and written explanations. Finally, while some have a preference in learning actively and interactively; others function more individually.

Kolb [26] in his empirical learning model indicates that learning is an interactive procedure containing four different modes of learning: (1) Active Experimentation (AE); (2) Concrete Experience (CE); (3) Reflective Observation (RO); and (4) Abstract Conceptualization (AC). Concrete and abstract make up one continuum while Reflective and Active make up another continuum. Depending on where an individual falls within each continuum, four specific styles are defined: the accommodative (AE/CE), the assimilative (RO/AC), the convergent (AC/AE), and the divergent (CE/RO).

Mumford and Honey [27] started using the Learning Style Inventory (LSI) introduced by Kolb, a readily presented and very first diagnostic instrument, for observing how individuals learn.

Given that the four classes are linked to a modified variation of Kolb's empirical learning cycle, the relations with Kolb's Learning Style Inventory (LSI) remain significant. Therefore, for instance, activists are known to be qualified for having experience; reflectors review 
experience; theorists make conclusions from their experience; and pragmatists for relying on practical actions (see figure 1)

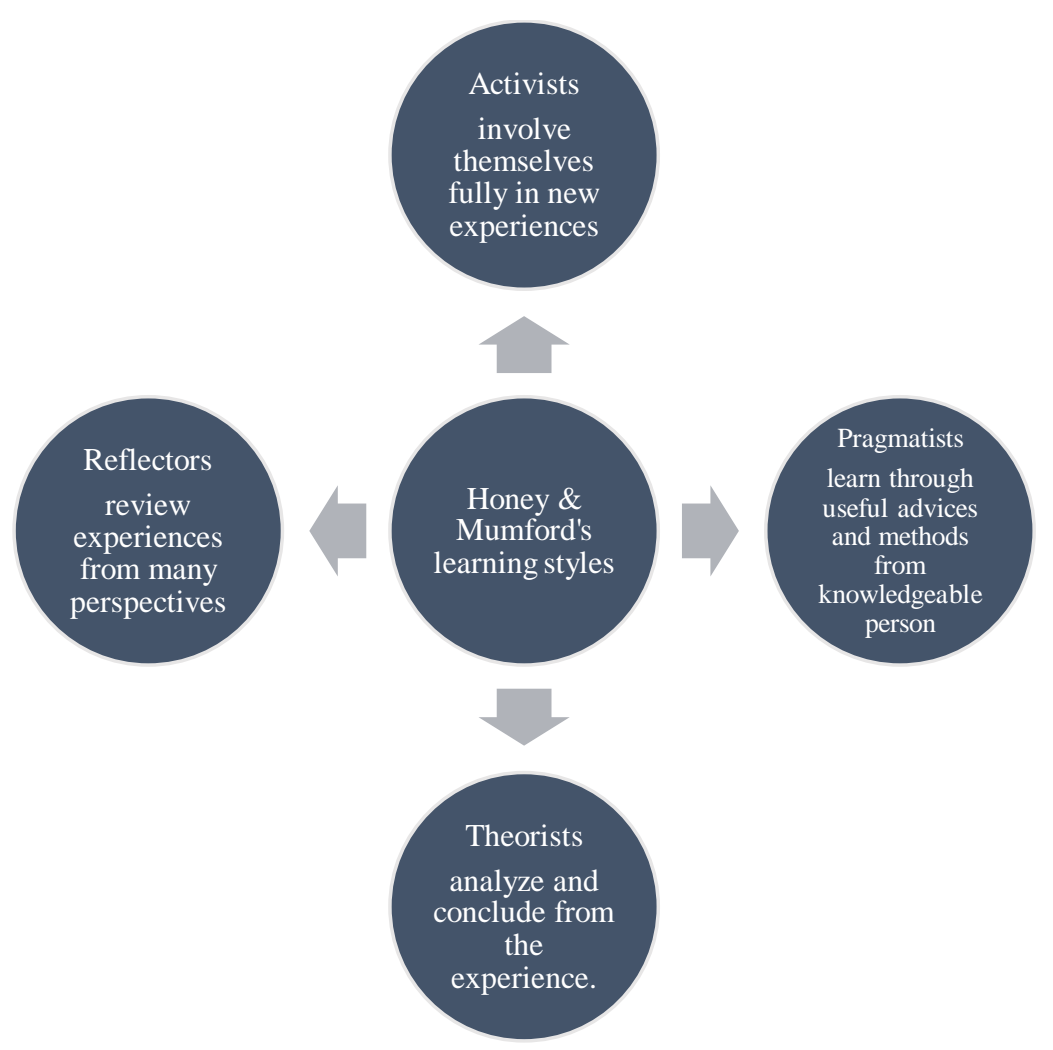

Fig. 1. Dimensions of Honey and Mumford's learning style

Table 1 shows the different researchers that have explored learning styles since the 80 s.

Table 1. Different researchers about learning styles

\begin{tabular}{l|c|c}
\hline Year & Researcher(s) & Measure \\
\hline 1985 & Gregorc & Gregorc Mind Style Delineator (GSD) \\
1985 & Myers-Briggs & Myers-Briggs Type Indicator (MBTI) \\
1989 & Hermann & Brain Dominance Instrument (HBDI) \\
1996 & Allinsom and Hayes & Cognitive Style Index (CSI) \\
1998 & Entwistle & Approaches to Study Inventory (ASI) \\
1998 & Riding & Cognitive Styles Analysis (CSA) \\
1998 & Vermunt & Inventory of Learning Styles (ILS) \\
1999 & Sterberg & Thinking Styles \\
1999 & Kolb & Learning Style Inventory (LSI) \\
2000 & Honey \& Mumford & Learning Styles Questionnaire (LSQ) \\
\hline
\end{tabular}




\begin{tabular}{c|c|c}
\hline 2001 & Apter & Motivational Style Profile (MSP) \\
2002 & Jackson & Learning Styles Profiler (LSP) \\
2003 & Dunn \& Dunn & Productivity Environmental Preference \\
& & Survey (PEPS) \\
\hline
\end{tabular}

\subsubsection{Leaning styles and problem solving}

There are few investigations in the literature that assess the connection between learning styles and problem-solving abilities. Bhat [28] found some support for this when he concluded that learning styles have effects on the students' problem-solving ability and that among all learning styles assimilator had the better problem-solving ability.

More recently, a study by Aljaberi [29] determined significant differences between the students' learning styles in solving the mathematical problems. His research also shows the Activist-Reflector style the most preferred style and also the superior performance in mathematical problems.

Similarly, Sebastian [30] reported that student's level of difficulties for computational and conceptual might be influenced by his/her learning style in solving problems. The accommodator and assimilator students are expected to have average difficulty level with conceptually difficult problems; while a low and high difficulty level are expected of converger and diverger students respectively. For computationally difficult problems, convergers have a low difficulty level; while assimilators tend to have average to high difficulty level. Both the diverger and accommodator tend to have an average difficulty level. Others such as Sirin \& Güzel [31], who used the Problem-solving Inventory [32] and the Learning Style Inventory [26] found that the students' learning style types are not related to their problem-solving abilities.

Conversely, it was observed that problem-solving abilities had a negative correlation with abstract conceptualization (AC) learning style and positive relationship with reflective-observation (RO) learning style. The students' problem-solving ability levels were perceived as poorer than expected [31].

\subsubsection{Dependency}

Individuals seek security, support, assurance, and guidance from outside themselves as the result of personal dependency. Another person, a social unit or a symbolic belief system are some examples from which individuals are given help and support. The desired support can be physical (reliance on caregiver), cognitive (affiliation between a learner and instructor) and/or emotional (dependence on someone else to ensure and love).

People vary in the quantity of convenience and assistance required from others. Some individuals are extremely dependent on those around them, while others operate more independent. 
Various evaluation instruments have been established to evaluate levels of interpersonal dependency. Various measures of dependency have been established since the idea of dependency is of interest to scientists in widespread areas. In table 2 , different scales to measure the personal dependency are presented.

Table 2. Different scales to measure the personal dependency

\begin{tabular}{|c|c|c|}
\hline Year & Researcher(s) & Scale (latest version) \\
\hline 1949 & Blum & $\begin{array}{l}\text { Blacky Test Oral Dependency } \\
\text { Scale (BTODS) }\end{array}$ \\
\hline 1956 & Kagan \& Mussen & $\begin{array}{l}\text { Thematic Apperception Test } \\
\text { dependency scale (TAT) }\end{array}$ \\
\hline 1967 & Masling et al. & $\begin{array}{c}\text { Rorschach Oral Dependency } \\
\text { scale (ROD) }\end{array}$ \\
\hline 1976 & Blatt et al. & $\begin{array}{l}\text { Depressive Experiences } \\
\text { Questionnaire (DEQ) }\end{array}$ \\
\hline 1977 & Hirschfelf et al. & $\begin{array}{l}\text { Interpersonal Dependency } \\
\text { Inventory (IDI) }\end{array}$ \\
\hline 1983 & Beck et al. & $\begin{array}{l}\text { Sociotropy-Autonomy Scale } \\
\text { (SAS) }\end{array}$ \\
\hline 1987 & Zimmerman \& Coryell & $\begin{array}{l}\text { Inventory to Diagnose } \\
\text { Depression - Lifetime version } \\
\text { (IDD-L) }\end{array}$ \\
\hline 1991 & Morey & $\begin{array}{l}\text { Personality Assessment } \\
\text { Inventory (PAI) }\end{array}$ \\
\hline 1994 & Paulhus & $\begin{array}{c}\text { Balanced Inventory of Desirable } \\
\text { Responding (BIDR) }\end{array}$ \\
\hline 1996 & Beck et al. & $\begin{array}{c}\text { Beck Depression Inventory - II } \\
\text { (BDI-II) }\end{array}$ \\
\hline 2008 & Ben-Porath \& Tellegen & $\begin{array}{l}\text { Minnesota Multiphasic } \\
\text { Personality Inventory - the latest } \\
\text { version Restructured Form } \\
\text { (MMPI-2-RF) }\end{array}$ \\
\hline 2015 & Millon et al. & $\begin{array}{l}\text { Millon Clinical Multiaxial } \\
\text { Inventory - Fourth } \\
\text { Edition (MCMI-IV) }\end{array}$ \\
\hline
\end{tabular}

\subsubsection{Dependency and problem solving}

Some research has evaluated the association between dependency and problem-solving skills. Research studies performed in the previous 30 years on dependency reveals that it relates to problem-solving. Ronning et al. [33] discovered students with lower level of dependency significantly outperformed than students with higher level of dependency on problems. Although students with higher level of dependency may well benefit from thoroughly structured direction and specific goals. Similarly, a research study by Hagaa et al. [34] reveals that problem solving is likewise associated with dependency, however it keeps a substantial relation with depressive sign seriousness once reliance is statistically managed. 
More recently, Wang et al. [34] stated a nonsignificant difference in solving simple and intermediate problems, but a significant effect in solving a complex problem. They indicated that independent students solved complex problems much better than dependent students.

\subsubsection{Working memory capacity}

Memory is essential to experiences and keeping information over time that affects future actions [36]. We might not be able to establish or learn a language, establish relationships, nor individuality handle problems, if we were unable to keep in mind previous occasions [37]. Frequently, memory is comprehended as an information processing system that is comprised of a sensory processor, short-term (or working) memory, and long-lasting memory [38].

As a brain system, working memory make available temporary storage and the required information to perform the complex cognitive tasks (e.g. language comprehension) may be considered as the term working memory [39]. Working memory can be defined as essential element in several practical tasks [40]. Since several everyday tasks include actively keeping information in mind, manipulating, and combining them in memory, working memory is an essential element to completing tasks. The amount of working memory (WM) capacity may determine how individuals perform different real-world cognitive tasks [41].

Over the past 30 years, numerous approaches have been proposed to study individual differences in working memory capacity (WMC). According to Conway et al. [42], perhaps a complex span paradigm is the best known and most common task to measure WMC. Several researchers on individual differences in WMC make this design solely by one or more complex tasks. Consequently, there is a very recent theory of how individual differences in WMC (perhaps very limited) can impact a complex span task class (e.g., [43], [44], and [45]).

\subsubsection{Working memory and problem solving}

Working memory maintains newly processed information to connect it to the newest input and also it holds the information to construct an overall representation of the problem. Therefore, Swanson \& BeebeFrankenberger [46] observed an association between the working memory and arithmetic problem solving ability for elementary school students.

Similarly, Barrouillet \& Lépine [47] reported that both the efficiency and frequency of the retrieval strategy are influenced by the children's working memory capacities in simple mathematics problemsolving. Children with higher WMC completed retrieval tasks quicker. A study by Beilock \& Carr [48] assessed the effects of working memory and pressure on students' ability to solve mathematical problems. In conditions where participants did not have any external pressure (e.g., time), they found individuals with low working memory (LWM) capacity solved the high-demand problems poorer. Nevertheless, in the condition 
where participants were under time pressure, the level of achievement for LWM was not decreased. However, time pressure impacts on the students with higher level of WM.

The work by Ashcraft \& Krause [49] indicated that by increasing the number of steps in multistep problems, the reliance on working memory is increased. Similarly, when the need to retain intermediate values and goals is increased, working memory capacity becomes much more important. To solve mathematical problems, Wiley \& Jarosz [50] have found an association between that students' performance and their working memory capacity. They also found the working memory capacity can improve the attention controlling, decrease distraction, and confine the problem solvers to search through a problem space. In analytic problem-solving contexts, the higher level of working memory capacity resulted usually better performance.

\section{Proposed Model of Team Effectiveness}

Figure 2 outlines an integrative model of attributes propped to impact team performance for collaborative problem solving. Several research questions are proposed based on the individual moderating variables of learning style, dependency, and working memory capacity:

1. Is there a difference in the pairs of individuals performance (amount of time required and accuracy (number of errors)) to complete a simple and a complex task?

2. Are the pairs of individuals' performances related to the composition of the groups?

3. How does performance vary based on the composition of the groups?

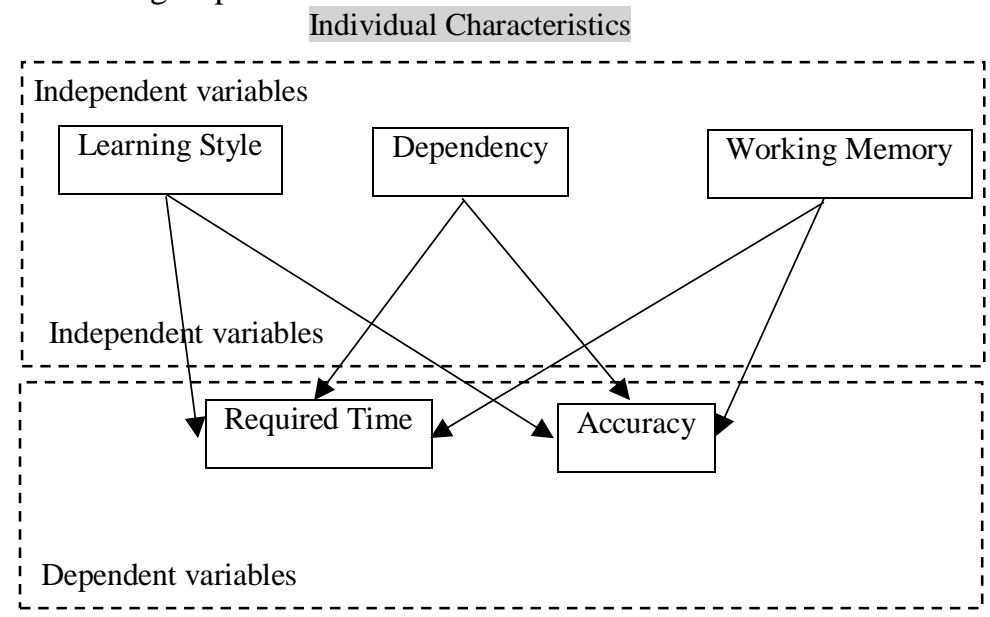

Performance Effectiveness in Collaborative Problem Solving

Fig. 2. Research model of individual learning style, dependency, and working memory on collaborative problem solving 


\subsection{Summary of Hypotheses}

Several hypotheses (Table 3) are proposed to answer these research questions looking at both main and interaction effects of the individual team member attributes.

Table 3. Summary of proposed hypotheses

\begin{tabular}{|c|c|c|}
\hline & Hypotheses & Rationale \\
\hline \multirow{3}{*}{ 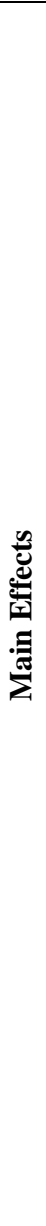 } & $\begin{array}{l}\mathrm{H} 1_{\mathrm{a}-\mathrm{b}} \text { The preferred Learning } \\
\text { Styles has a significant effect on } \\
\text { performance effectiveness in } \\
\text { collaborative problem solving } \\
\text { (amount of time required and } \\
\text { accuracy) }\end{array}$ & $\begin{array}{l}\text { Need to evaluate how } \\
\text { learning styles and } \\
\text { collaborative problem-solving } \\
\text { abilities are connected. } \\
\text { Research has not shown that } \\
\text { there is evidence that one } \\
\text { preference is better than } \\
\text { another. }\end{array}$ \\
\hline & $\begin{array}{l}\mathrm{H} 2_{\mathrm{a}-\mathrm{b}} \text { The level of Personal } \\
\text { Dependency has a significant } \\
\text { effect on performance } \\
\text { effectiveness in collaborative } \\
\text { problem solving (amount of } \\
\text { time required and accuracy) }\end{array}$ & $\begin{array}{l}\text { This evaluates the association } \\
\text { between dependency and } \\
\text { collaborative problem-solving } \\
\text { skills. The analysis of social } \\
\text { science literature clearly } \\
\text { shows that individual } \\
\text { dependency was considered } \\
\text { as negative [51] and [52] or } \\
\text { positive [53] and [54] terms. } \\
\text { On the one hand, individual } \\
\text { reliance is equal to weakness } \\
\text { and obstruction to develop an } \\
\text { independent and mature } \\
\text { individual. On the other hand, } \\
\text { individual reliance is } \\
\text { considered as a fundamental } \\
\text { human inspiration to perform } \\
\text { essential adaptive tasks. }\end{array}$ \\
\hline & $\begin{array}{l}\text { H3a-b The level of Working } \\
\text { Memory Capacity has a } \\
\text { significant effect on } \\
\text { performance effectiveness in } \\
\text { collaborative problem solving } \\
\text { (amount of time required and } \\
\text { accuracy) }\end{array}$ & $\begin{array}{l}\text { Working memory and } \\
\text { problem-solving skills are } \\
\text { related. The amount of } \\
\text { working memory (WM) } \\
\text { capacity may determine how } \\
\text { individuals perform different } \\
\text { real-world cognitive tasks } \\
\text { [41]. }\end{array}$ \\
\hline
\end{tabular}




\begin{tabular}{|c|c|c|c|}
\hline \multirow{2}{*}{ 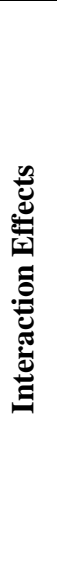 } & 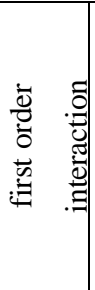 & $\begin{array}{l}\mathrm{H} 4_{\mathrm{a}-\mathrm{b},}, \mathrm{H} 5_{\mathrm{a}-\mathrm{b}} \text {, and H6 } \mathrm{H}-\mathrm{b} \text { There is } \\
\text { no difference in Team Problem } \\
\text { Solving Outcomes (amount of } \\
\text { time required and accuracy) } \\
\text { based on all possible pairs of } \\
\text { independent variables (Learning } \\
\text { Styles, Dependency and } \\
\text { Working Memory Capacity). }\end{array}$ & \multirow{2}{*}{$\begin{array}{l}\text { Noteworthy interactions } \\
\text { might be observed to } \\
\text { demonstrate that there are } \\
\text { mixtures of traits more (or } \\
\text { less) productive than } \\
\text { anticipated, providing proof } \\
\text { that group composition } \\
\text { influences group } \\
\text { performance. Hence, some } \\
\text { mixtures of individual traits } \\
\text { may yield group performance } \\
\text { differences. They might } \\
\text { contribute considerably to the } \\
\text { variation in group } \\
\text { performance efficiency. }\end{array}$} \\
\hline & 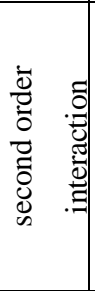 & $\begin{array}{l}\text { H7 a-b There is no difference in } \\
\text { Team Problem Solving } \\
\text { Outcomes (amount of time } \\
\text { required and accuracy) based on } \\
\text { all three independent variables } \\
\text { (Learning Styles, Dependency } \\
\text { and Working Memory } \\
\text { Capacity). }\end{array}$ & \\
\hline
\end{tabular}

\section{Conclusion and Justification}

Teams solve many of our complex problems in society. As a result, it is important to understand how to improve team performance. This research proposes to understand critical individual characteristics (e.g., learning style, dependency, and working memory capacity) of team members and their interactive effect upon collaborative problem solving. With an understanding of the proposed attributes, guidance could be developed that could impact team performance based on elements such as team composition, team guidance toward a goal or even the means in which teams interact. While the literature on understanding teams is vast, our knowledge is still very limited at understanding the elements that contribute to team performance. This research hopes to close some of that gap in knowledge.

\section{References}

1. Hackman, J. R. (1990). Groups that work and those that don't (No. E10 H123). Jossey-Bass..

2. Pieper, T. M., Klein, S. B., \& Jaskiewicz, P. (2008). The impact of goal alignment on board existence and top management team composition: Evidence from family-influenced businesses. Journal of Small Business Management, 46(3), 372-394.

3. National Research Council. (2015). Enhancing the effectiveness of team science. National Academies Press.

4. FRAMEWORK, D. C. P. S. (2013). PISA 2015 DRAFT COLLABORATIVE PROBLEM SOLVING FRAMEWORK.

5. Graesser, A. C., Fiore, S. M., Greiff, S., Andrews-Todd, J., Foltz, P. W., \& Hesse, F. W. (2018). Advancing the science of collaborative problem solving. Psychological Science in the Public Interest, 19(2), 59-92.

6. Fiore, S. M., Graesser, A., \& Greiff, S. (2018). Collaborative problem-solving education for the twenty-first-century workforce. Nature Human Behavior, 1.

7. Sottilare, R. A., Burke, C. S., Salas, E., Sinatra, A. M., Johnston, J. H., \& Gilbert, S. B. (2018). Designing adaptive instruction for teams: A meta-analysis. International Journal of Artificial Intelligence in Education, 28(2), 225-264. 
8. Fiore, S. M., Graesser, A., Greiff, S., Griffin, P., Gong, B., Kyllonen, P., ... \& Soulé, H. (2017). Collaborative Problem Solving: Considerations for the National Assessment of Educational Progress.

9. Griffin, P., \& Care, E. (Eds.). (2014). Assessment and teaching of 21st century skills: Methods and approach. Springer.

10. Von Davier, A. A., Zhu, M., \& Kyllonen, P. C. (Eds.). (2017). Innovative assessment of collaboration. Springer.

11. Hackman, J. R. (1987). The design of work teams. In J. W. Lorsch (Ed.), Handbook of organizational behavior (pp. 315-342). Englewood Cliffs, NJ: Prentice Hall.

12. Guzzo, R. A., \& Shea, G. P. (1992). Group performance and intergroup relations in organizations. In M. D. Dunnette \& L. H. Hough (Eds.), Handbook of industrial and organizational psychology (Vol. 3, 2nd ed., pp. 269-313). Palo Alto, CA: Consulting Psychologists Press.

13. McGrath, J. E. (1964). Social psychology: A brief introduction. New York: Holt, Rinehart \&Winston.

14. Gladstein, D. L. (1984). Groups in context: A model of task group effectiveness. Administrative Science Quarterly, 29, 499-517.

15. Cattell, R. B. (1948). Concepts and methods in the measurement of group syntality. Psychological Review, 55, 48-63.

16. Haythorn, W. (1953). The influence of individual members on the characteristics of small groups. Journal of Abnormal and Social Psychology, 48, 276-284.

17. Senior, B., \& Swailes, S. (2004). The dimensions of management team performance: a repertory grid study. International Journal of Productivity and Performance Management, 53(4), 317-333.

18. Sundstrom, E., De Meuse, K. P., \& Futrell, D. (1990). Work teams: Applications and effectiveness. American Psychologist, 15, 120-133.

19. Campion, M. A., Medsker, G. J., \& Higgs, A. C. (1993). Relations between work group characteristics and effectiveness: Implications for designing effective work groups. Personnel psychology, 46(4), 823-847.

20. Campion, M. A., Papper, E. M., \& Medsker, G. J. (1996). Relations between work team characteristics and effectiveness: A replication and extension. Personnel Psychology, 49,429452.

21. Julie Yazici, H. (2005). A study of collaborative learning style and team learning performance. Education+ training, 47(3), 216-229.

22. Hackman, J. R., \& Wageman, R. (2005). A theory of team coaching. Academy of Management Review, 30(2), 269-287.

23. Coffield, F., Moseley, D., Hall, E., \& Ecclestone, K. (2004). Learning styles and pedagogy in post-16 learning: A systematic and critical review.

24. Willingham, D. T., Hughes, E. M., \& Dobolyi, D. G. (2015). The scientific status of learning styles theories. Teaching of Psychology, 42(3), 266-271.

25. Pashler, H., McDaniel, M., Rohrer, D., \& Bjork, R. (2008). Learning styles: Concepts and evidence. Psychological science in the public interest, 9(3), 105-119.

26. Kolb, D. A. (1984). Experiential learning: Experience as the source of learning and development. Englewood Cliffs, NJ: Prentice Hall Inc.

27. Honey, P., \& Mumford, A. (1986). Using your learning styles. Chartered Institute of Personnel and Development.

28. Bhat, M. A. (2014). The effect of learning styles on problem solving ability among high school students. International Journal Advances in Social Science and Humanities, 2(7), 1-6.

29. Aljaberi, N. M. (2015). University Students' Learning Styles and Their Ability to Solve Mathematical Problems. International Journal of Business and Social Science, 6(4).

30. Sebastian, M. A. (2017). Students' Gender, Learning Style, and Difficulties in Solving Problems in College Algebra. 
31. Sirin, A., \& Güzel, A. (2006). The Relationship between Learning Styles and Problem Solving Skills among College Students. Educational Sciences: Theory \& Practice, 6(1).

32. Heppner, P. P., \& Petersen, C. H. (1982). The development and implications of a personal problem-solving inventory. Journal of counseling psychology, 29(1), 66.

33. Ronning, R. R., McCurdy, D., \& Ballinger, R. (1984). Individual differences: A third component in problem-solving instruction. Journal of Research in Science Teaching, 21(1), 71-82.

34. Haaga, D. A., Fine, J. A., Terrill, D. R., Stewart, B. L., \& Beck, A. T. (1995). Social problemsolving deficits, dependency, and depressive symptoms. Cognitive Therapy and Research, 19(2), 147-158.

35. Wang, L. J., Wang, X., \& Ren, M. Z. (2003). Field-dependent-independent cognitive style in solving dynamics problems. Psychological reports, 92(3), 867-880.

36. Sherwood, L. (2015). Human physiology: from cells to systems. Cengage learning.

37. Eysenck, M. W., \& Brysbaert, M. (2018). Fundamentals of cognition. Routledge.

38. Baddeley, A. (2007). Working memory, thought, and action (Vol. 45). OUP Oxford.

39. Baddeley, A. (1992). Working memory. Science, 255(5044), 556-559.

40. Baddeley, A. D., \& Hitch, G. (1974). Working memory. In Psychology of learning and motivation (Vol. 8, pp. 47-89). Academic press.

41. Engle, R. W. (2002). Working memory capacity as executive attention. Current directions in psychological science, 11(1), 19-23.

42. Conway, A. R., Kane, M. J., Bunting, M. F., Hambrick, D. Z., Wilhelm, O., \& Engle, R. W. (2005). Working memory span tasks: A methodological review and user's guide. Psychologic bulletin \& review, 12(5), 769-786.

43. Barrouillet, P., Portrat, S., \& Camos, V. (2011). On the law relating processing to storage in working memory. Psychological Review, 118(2), 175.

44. Unsworth, N., \& Engle, R. W. (2007). On the division of short-term and working memory: an examination of simple and complex span and their relation to higher order abilities. Psychological bulletin, 133(6), 1038.

45. Oberauer, K., Lewandowsky, S., Farrell, S., Jarrold, C., \& Greaves, M. (2012). Modeling working memory: An interference model of complex span. Psychonomic bulletin \& review, 19(5), 779-819.

46. Swanson, H. L., \& Beebe-Frankenberger, M. (2004). The relationship between working memory and mathematical problem solving in children at risk and not at risk for serious math difficulties. Journal of Educational Psychology, 96(3), 471.

47. Barrouillet, P., \& Lépine, R. (2005). Working memory and children's use of retrieval to solve addition problems. Journal of Experimental Child Psychology, 91(3), 183-204.

48. Beilock, S. L., \& Carr, T. H. (2005). When high-powered people fail: Working memory and "choking under pressure" in math. Psychological science, 16(2), 101-105.

49. Ashcraft, M. H., \& Krause, J. A. (2007). Working memory, math performance, and math anxiety. Psychonomic bulletin \& review, 14(2), 243-248.

50. Wiley, J., \& Jarosz, A. F. (2012). Working memory capacity, attentional focus, and problem solving. Current Directions in Psychological Science, 21(4), 258-262.

51. Bornstein, R. F. (1993). The dependent personality. New York, NY, US: Guilford Press.

52. Greenberg, J. R., \& Mitchell, S. A. (1983). Object relations in psychoanalytic theory Cambridge. MA: Harvard UP.

53. Kelley, H. H. (2013). Personal relationships: Their structures and processes. Psychology Press.

54. Folkman, S. (2013). Stress: appraisal and coping. In Encyclopedia of behavioral medicine (pp. 1913-1915). Springer, New York, NY. 